\title{
Manipulating Protein Degradability in the Rumen to Support Higher Ruminant Production
}

\author{
Budi Haryanto \\ Indonesian Research Institute for Animal Production, PO Box 221, Bogor 16002 \\ budiharyanto_51@yahoo.com
}

(Diterima 2 Mei 2014 - Direvisi 25 Juli 2014 - 25 Agustus 2014)

\begin{abstract}
Dietary protein is digested to a certain extent in the rumen causing decreases its potency as source of amino acids for the animal. Dietary protein should mostly reach the intestines where the protein digestion takes place and absorption occurs in the form of intact amino acids and subsequently becomes nutrient deposition in muscles or milk. The higher muscle or milk protein synthesis, the higher the protein in the products of animal, as long as energy for the metabolism is available. Strategies of feeding rumen degradable versus undegradable protein in ruminant have become a research interest for decades. Technologies of dietary protein protection to reduce its degradability in the rumen by heating, chelating or coating have been developed.
\end{abstract}

Key words: Protein, degradability, protection, rumen

ABSTRAK

Manipulasi Degradabilitas Protein di Dalam Rumen untuk Meningkatkan Produksi Ternak Ruminansia

Berhubung sebagian dari protein di dalam pakan akan dicerna di rumen, maka pakan tersebut akan kehilangan fungsinya sebagai sumber asam amino bagi ternak. Protein pakan sebaiknya sebagian besar tidak didegradasi di dalam rumen sehingga terbawa sampai ke usus dimana akan terjadi proses hidrolisis dan penyerapan asam amino yang selanjutnya akan digunakan dalam deposisi nutrien di dalam jaringan tubuh ternak. Dengan adanya deposisi protein, produk ternak akan mengandung protein lebih tinggi dengan syarat energi untuk metabolisme tersedia. Strategi pemberian pakan mengandung protein terdegradasi versus protein tidak terdegradasi di dalam rumen ternak ruminansia sudah lama menjadi perhatian penelitian. Teknologi proteksi protein bahan pakan untuk menurunkan angka degradabilitasnya di dalam rumen melalui pemanasan, khelasi atau pelapisan telah dikembangkan.

Kata kunci: Protein, kecernaan, proteksi, rumen

\section{INTRODUCTION}

Efficiency of nutrient utilization in ruminants is a function of the nutrient digestion, in the rumen and post rumen tract, absorption of the digested nutrient through the rumen wall or intestinal villies, and metabolism in animal organs or tissues. It has been decades that researchers investigated the nutrient fate along the digestive tract, and finally elucidated that the physical characteristics of nutrient in terms of their degradability and interactions play an important role in affecting the efficiency of nutrient utilization. Energy and amino acid availability in a synchronized time have been considered to be positively affecting the ruminant productivity. For the dietary protein, it is important that the protein entity is not entirely degraded into carbon chain and ammonia in the rumen due to the fact that degraded protein means losing the potency as source of amino acids for the host. Besides, the dietary amino acids are required for the organ or tissue metabolisms for a better animal production.

Researchers have developed the efforts to protect dietary protein from rumen degradation with the expectation that the dietary protein will subsequently be hydrolyzed in the post rumen tract and become source of amino acids for further metabolism after being absorbed through the intestinal walls. It is expected that higher dietary rumen bypass protein will increase ruminant productivity, especially for the meat and milk to have higher protein content.

The objectives of the present paper are to elucidate the importance of rumen bypass protein on the ruminant production, and to describe the efforts that have been carried out to produce rumen bypass protein. 


\section{RUMINANT DIGESTION SYSTEM}

Digestion of feed organic matter in ruminants relies on the work of microbes in the rumen. There are different patterns of digestion between dietary components i.e., protein, carbohydrates and fat components which also involve different microbial species that working on each component. The role of bacteria, protozoa, fungi and bacteriophages in the utilization of polysaccharides in the rumen is accomplished by the sequential activities of consortia of rumen microorganisms (Annison \& Bryden 1998). However, there is a negative relationship between population of protozoa and microbes which is governed by the fluctuation of $\mathrm{pH}$ of the rumen fluid. The rumen fluid $\mathrm{pH}$ itself is affected by the degree of feed organic matter degradation. In relation to nitrogen $(\mathrm{N})$ metabolism, the predation of bacteria by protozoa increases protein turnover in the rumen and reduces the efficiency of microbial protein production (Annison \& Bryden 1998).

The fact that ruminants eat primarily fibrous materials, therefore those microbes having the ability to produce cellulose degrading enzymes will be more important as compared to those producing protein and fat degrading enzymes. Consumption of fiber rich diets increased bacterial and fungal diversity in the rumen and also increased the concentrations of cellulolytic microorganisms, including protozoa $(+38 \%)$, anaerobic fungi $(+59 \%)$, and methanogens $(+27 \%)$ as compared to feeding starch rich diets in dairy cows (Belanche et al. 2012). However, the orchestra of all microbes in the rumen is required to synergize overall effects on the feed degradation and fermentation. The ultimate products of rumen microbial activities are volatile short-chain fatty acids (SCFA) which are important sources of energy for the animal, with concomitant production of $\mathrm{CO}_{2}$, methane and water.

The products of fermentation in the form of volatile SCFA will be predominantly absorbed into the blood circulatory system from the rumen. Meanwhile the site of amino acid and fat absorption will be in the lower part of the digestive tract, especially in the intestines. SCFA absorption also accelerates urea transport into the rumen, which via ammonium recycling, may remove protons from rumen to the blood. Ammonium absorption into the blood is also stimulated by luminal SCFA. It is suggested that the interacting transport processes for SCFA, urea, and ammonia represent evolutionary adaptations of ruminants to actively coordinate energy fermentation, protein assimilation, and $\mathrm{pH}$ regulation in the rumen (Aschenbach et al. 2011).

Therefore, strategy in feeding ruminants should consider the timely matched availability among nutrients that can be metabolized at the level of animal tissue. Balancing energy and nitrogen in the rumen is a key to both profitability and environmental sustainability (Belanche et al. 2012). This is supported by earlier finding of an experiment in sheep that synchronizing the rate of supply of $\mathrm{N}$ and energyyielding substrates to the rumen micro-organisms based upon ingredient in situ degradation data can improve microbial protein flow at the duodenum and the efficiency of microbial protein synthesis (Sinclair et al. 1993). On the contrary, synchronizing starch and protein degradation in rumen was reported to have no effect on the intake and digestibility of nutrients in sheep (Biricik et al. 2006), in which rumen ammonia-N concentrations were not affected by the degradability characteristics of protein. Meanwhile the rumen $\mathrm{pH}$ and acetate: propionate ratios were higher in diets containing slowly degradable starch than in diets containing rapidly degradable starch. Propionic acid was higher in diets containing rapidly degradable starch than in diets containing slowly degradable starch. Increased concentrate proportion in the diet ( $72 \%$ versus $52 \%$ of dry matter) of dairy cows resulted in reduced rumen ammonia concentration and enhanced ammonia utilization for milk protein synthesis (Agle et al. 2010). The high-concentrate diet decreased rumen $\mathrm{pH}$ and ammonia concentration and increased propionate concentration compared with lowconcentrate diet. Acetate: propionate ratio was greater for low-concentrate than for high-concentrate diet. Rumen methane production and microbial protein synthesis were unaffected by diet. Dry matter intake was similar among diets, but milk yield was increased by high-concentrate compared with low-concentrate (36.0 and $33.2 \mathrm{~kg} / \mathrm{d}$, respectively).

\section{Rumen fermentation and energy generation}

Fiber in feeds is composed of cellulose and hemi cellulose fractions in which the digestion is dependent upon the availability of microbial enzyme in the rumen. The ultimate results of its degradation and fermentation consisted of volatile short-chain fatty acids (SCFA), primarily of acetic, propionic and butyric acids with minute amounts of iso-acids and valeric acid. These short-chain fatty acids are absorbed mostly in the rumen, and can be used subsequently as source for energy by the animal. True digestion of dietary organic matter (OM) and neutral detergent fiber (NDF) were affected by $\mathrm{pH}$, but not by type of diet. Total volatile fatty acids were reduced by $\mathrm{pH}$ and were greater in high-concentrate diets than in high-forage diets. Acetic and butyric acid concentrations were reduced by $\mathrm{pH}$ but were not affected by diet. Propionic acid concentration increased as the $\mathrm{pH}$ decreased and was greater in high-concentrate than in high-forage diets (Calsamiglia et al. 2008). Therefore, high fiber diets 
may have a greater energy generating sources as compared to the low fiber diets.

Dietary protein may be degraded in the rumen into carbon chain and ammonia components; by which the carbon chain may be further fermented into short chain volatile fatty acids as happened to the dietary fiber components. As a consequence, the degraded dietary proteins will lose its potency as source of amino acids for the animal but generating energy when ruminal fermentation commenced.

\section{Use of rumen undegradable protein in the diet}

Protein evaluation systems recently use the concept of metabolisable protein (MP), rumen degradable protein (RDP) and rumen undegradable protein (RUP). Even though mobilisation of protein itself does not seem to have negative effects on reproduction, when protein is extensively degraded in the rumen or used as an energy source, metabolic residues like ammonia and urea will result which may be detrimental to reproduction and fertility (Tamminga 2006).

The protein component of feed is expensive; it consisted of amino acids and if highly soluble in rumen then it will be rapidly deaminated by proteolytic enzymes of rumen microbes to produce ammonia and carbon chain. Practically, the protein that has been deaminated will lose its function as source of amino acids for the animal, even though the ammonia in turn can be used by microbes to synthesize their protein mass. Furthermore, these microbial proteins will be used by the animal as source of amino acids after being hydrolyzed in the intestines. Bypassing the rumen means change the sites of nutrient digestion and absorption and provides a mechanism for supplementing outflow of nutrients from the rumen. A feasible approach to production of animal protein from ruminants would be (1) utilization of non-protein nitrogen (NPN) for rumen microbial protein synthesis, (2) maximization of rumen bypass protein, and (3) supplementation with rumen non-degradable amino acids (Chalupa 1975). Mechanistic models of $\mathrm{N}$ utilization indicate that reducing dietary protein concentration, matching protein degradability to the microbial requirement, and increasing the energy status of the animal will reduce the output of $\mathrm{N}$ as waste (Kebreab et al. 2009). Therefore, it is suggested that the strategy of feeding protein in ruminants should consider the portion of undegradable protein in the rumen so that it can be used as source of amino acids for further metabolism in the animal tissue. Positive effects of feeding more rumen un-degraded protein (RUP) in lactating dairy cows were indicated by increased feed efficiency and milk fat content $(1.8 \mathrm{~kg} / \mathrm{d}$ greater FCM and $0.08 \mathrm{~kg} / \mathrm{d}$ greater fat), but milk protein content was lower and milk urea $\mathrm{N}$ and urinary urea excretion were elevated (Broderick et al. 2009). The ratio between rumen degradable peptide supply and the peptide requirement of microbes for the optimum fermentation has been studied in steers (Brooks et al. 2012); the results indicated that average daily gain and G:F displayed a quadratic effect with greater $A D G$ and $G: F$ at higher and lower rumen degradable peptide levels. It was concluded that increasing positive balancing rumen degradable peptide supply to predicted requirement (required minus supply) improved fermentation efficiency and microbial output, which in turn improved animal performance.

There are some feedstuffs that contain protein with low degradability characteristics such as blood meal. Variation in protein degradation also occurs in forages depending on the tannin content. Crude protein degradation was higher for lucerne (Medicago sativa) than for white clover (Trifolium repens), and these two tannin-free species exhibited greater crude protein degradation than crownvetch (Coroinilla varia) and birdsfoot trefoil (Lotus corniculatus). In birdsfoot trefoil, crude protein degradation was negatively correlated to condensed tannin content but positively correlated to dry matter degradation (Julier et al. 2003).

The rate of degradation of the slowly degradable $\mathrm{CP}$ fraction ranged from 11.8 for soy bean meal (SBM) to $2.7 \% / \mathrm{h}$ for reduced-fat distillers dried grains with solubles (RFDGS). Rumen-undegradable protein varied widely (32.3 to $60.4 \%$ ), with RFDGS having the greatest and SBM the lowest concentrations. The intestinal digestibility for rumen undegradable protein (IDP) was greatest for SBM, expeller SBM, and extruded soy bean meal (ES) $(97.7 \% \pm 0.75)$, whereas IDP of distillers grains (DG) products was $92.4 \% \pm$ 0.87 . Similarly, total digestible protein was greatest (99.0\%) for soybean products, whereas DG products had a total digestible protein of $96.0 \%$. (Mjoun et al. 2010).

Goats fed pelleted total mixed ration supplemented with low-degradable protein diet (LD diet) containing corn gluten meal showed higher milk fat, protein and casein concentration as compared to those fed high-degradable protein diet (HD diet) containing soybean meal, sunflower meal and urea (Laudadio \& Tufarelli 2010). This may be associated with the higher low degradable protein content of the corn gluten meal that can be converted into milk protein. However, for the highly soluble protein feedstuffs in the rumen, there are also possible to manipulate the degradability of protein in the feedstuffs by protecting its molecule from microbial enzyme attack. Methods of decreasing protein and amino acid degradation in the rumen include heat treatment, chemical treatment, encapsulation, and use of amino 
acid analogs (Chalupa 1975). Moderate concentrations of condensed tannin (CT) can be used to increase the efficiency of protein digestion; however the effects are not the same for all CT, but rather depend upon the concentration and structure of the CT (Min et al. 2003). This is probably related to the action of $\mathrm{CT}$ in reducing the protein degradability in the rumen; therefore increasing essential amino acids (EAA) absorption from the small intestine. By this means, it is indicated that the protein will pass through the rumen and reach the lower part of digestive tract in which this protein will be hydrolyzed to release the amino acids, and ready to be absorbed across the intestinal walls to the circulatory vessel. The un-digested dietary protein will be excreted as described in the following Illustration 1.

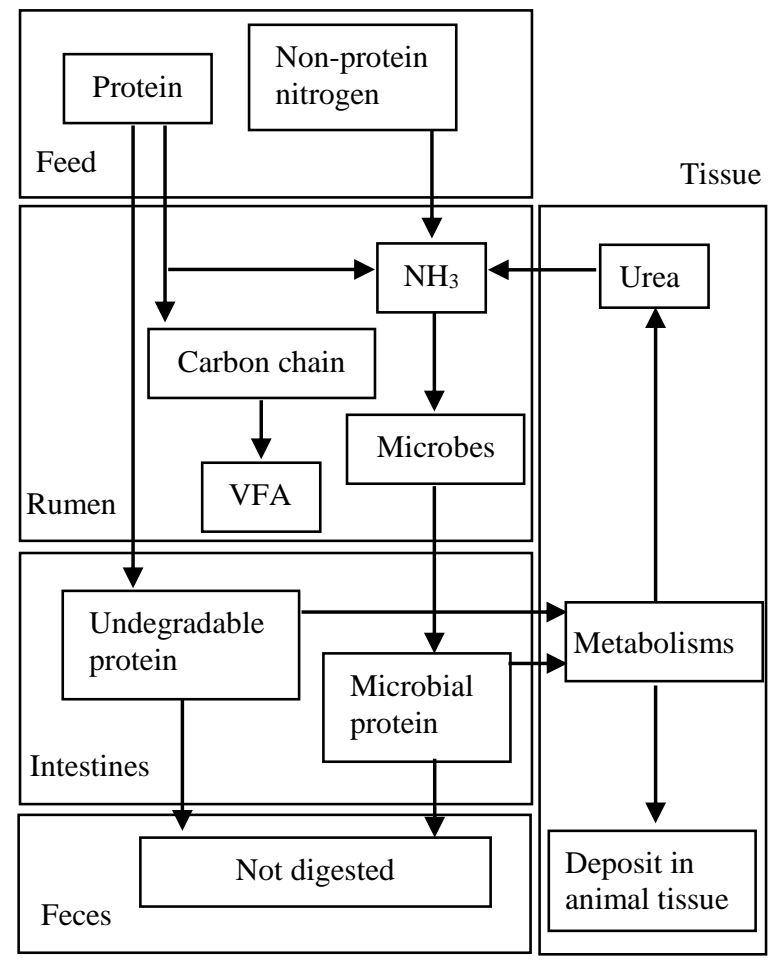

Illustration 1. Fate of dietary protein in the ruminant digestion system (personal document)

\section{TECHNOLOGY FOR PROTECTING PROTEIN}

Technology for dietary protein protection has been developed since more than 5 decades ago. It was initiated by the finding of browning Maillard effect showing that heating may reduce the degradation of protein in the digestive tract. Thereafter, physical, chemical, and even biological treatments have been developed to manipulate the dietary protein degradability.

Protection of protein from microbial enzyme degradation can be carried out by linking the protein molecule to several chemicals such as formaldehyde
(Spears et al. 1985) and tannic acid (Mezzomo et al. 2011; Coblentz \& Grabber 2013). Experimental reports have proved the effectiveness of using formaldehyde to make undegradable protein in the rumen. Treating soybean meal with $0.3 \mathrm{~g}$ formaldehyde/100 $\mathrm{g}$ may decrease availability of soybean meal protein for use by lactating dairy cows (Crooker et al. 1983). Calcium soaps of fatty acids can be used to coat proteins, thus reducing rumen degradability (Sklan \& Tinsky 1993). The use of Ca soaps to coat proteins appears to be useful to optimize protein supply to dairy cows while increasing ration energy density. However, there are possible to use other materials such as molasses to coat the protein molecule by which may reduce the effect of microbial enzyme attack so that the molecule of protein will be safely reach the hydrolyzing site in the postrumen tract. The principle of coating technique is that the process of attack by microbial enzyme to the protein molecule will be protected by the coating materials until the layer is completely taken off from the particle of protein molecule. Thereafter, the protein degrading enzyme has the chance to start working on the protein molecule. By the time, the protein molecule may have been flowed to the lower digestive tract, and therefore remain intact as poly peptide conformation. Technique of coating using molasses as the protein protector could be carried out with concentration of 20 $\mathrm{kg}$ molasses for every $100 \mathrm{~kg}$ protein feedstuff, followed by heating at $60-80^{\circ} \mathrm{C}$ or under bright sun light until dry with approximately $10 \%$ water content (Haryanto 2008).

\section{Response of livestock to feeding protected protein}

Response of animal to dietary intake can be seen as meat, milk, wool, work or other forms of animal production. The animal production can be used as indicator of energy balance. The excess of energy intake beyond those for maintenance, digestion and metabolism will be deposited as animal products in the form of fat. The optimal balance between energy and protein that can be metabolized in the animal tissue will determine the characteristic of animal products. In terms of beef cattle, the balance between quantity of metabolized energy and protein may be reflected as meat with high or low fat content depending on their ratio. Due to the fact that protein is an expensive feed, while microbial protein can also be used as source of protein for the animal, therefore it is recommended to increase the microbial protein synthesis while at the same time providing nitrogen in the form urea for the microbial protein synthesis accompanied by feeding undegradable protein feed.

Feeding lactating Holstein cows with different level of rumen degradable protein have been carried out by Reynal and Broderick (2005). The diets 
contained $37 \%$ corn silage, $13 \%$ alfalfa silage, and $50 \%$ concentrate (on dry matter basis). The concentrate contained solvent and lignosulfonate-treated soybean meal and urea, and was adjusted to provide RDP at $13.2,12.3,11.7$, and $10.6 \%$ of $\mathrm{DM}$ in diets, respectively. The results indicated that intake of feed dry matter (DM) and yield of milk, fat-corrected milk, and fat were not affected by treatments. However, dietary RDP had a positive linear effect on total $\mathrm{N}$ excretion, with urinary $\mathrm{N}$ accounting for most of the increase, and a negative linear effect on environmental $\mathrm{N}$ efficiency $(\mathrm{kg}$ of milk produced per $\mathrm{kg}$ of $\mathrm{N}$ excreted). Therefore, a compromise between profitability and environmental quality was achieved at a dietary RDP level of $11.7 \%$ of DM (Reynal \& Broderick 2005).

An experiment using a total of 432 crossbred yearling steers in a randomized block experiment was carried out by Wagner et al. (2010) to study the effects of rumen degradable intake protein (DIP) and rumen undegradable intake protein (UIP) concentration on feedlot performance. The results suggested a linear increase in final BW and ADG and a trend for a linear increase in DMI associated with increasing DIP concentration. Feed efficiency and NE (net energy) recovered from the diet were not influenced by dietary DIP concentration (Wagner et al. 2010).

The use of formaldehyde-treated soybean meal $(0.2 \%$ of $37 \%$ formaldehyde solution mixed with 100 $\mathrm{kg}$ soybean meal) in the diets for sheep have been successful in increasing the carcass percentage and meat:fat ratio (Haryanto 1992). Meanwhile, feeding protected palm kernel cake increased the sheep performance in the form of weight gain and carcass quality when the concentration in the diets ranged from 20 to $40 \%$ (Haryanto \& Jarmani 2010). Similar results were observed in growing goats when protected palm kernel cake was included in the concentrate (Supriyati \& Haryanto 2011).

\section{Relationship between intake of un-degraded protein and fermented organic matter}

Microbial growth in the rumen requires the availability of precursor elements for cell mass production such as carbon, nitrogen, sulfur, phosphorous and other minerals. These elements are obtained from the degradation of dietary nutrient in the rumen. The dietary nutrients can be differentiated into protein, carbohydrate, lipids, vitamins and minerals.
The degradation of protein is primarily involving the process of cutting off the poly peptide chains into oligo peptides, di peptides or single amino acids which is followed by the deamination to form ammonia and carbon chain depending on the amino acid structure. The ammonia will be used by microbes to build their protein mass, whereas the carbon chains will be fermented further to form volatile fatty acids.

The carbohydrate components either in the form of amylose, cellulose or hemicellulose will be degraded into oligosaccharides or their monomer of hexose or pentose molecules. These saccharides will be further degraded and fermented to some extent to form short chain volatile fatty acids. These volatile fatty acids will be used later on as source of energy by the animal. In evaluating the interaction of non-fiber carbohydrate (NFC) type, either starch or dextrose, and level of rumen degradable protein (RDP) supplementation (casein) on low-quality forage utilization in beef cattle (Arroquy et al. 2004), it was reported that there were no interaction occurred between non-fiber carbohydrate type and RDP level for intake or digestion measure. Total digestible OM intake increased with increasing supplemental RDP, but at a decreasing rate. Both forage and total $\mathrm{OM}$ intake responded linearly to increasing supplemental RDP; meanwhile digestion of OM increased linearly whereas NDF digestion tended to initially increase but then plateau.

The ratio between quantity of protein and energy that can be metabolized in the animal tissues will determine the quality of animal products as has been mentioned earlier. Crude protein supplements consisting of 20 to $60 \%$ undegradable protein intake can be effectively used by ruminants consuming lowquality forage without adversely affecting $\mathrm{N}$ efficiency and animal performance (Bohnert et al. 2002). Therefore, it is necessary that the dietary protein content should be to some extent resistant to microbial degradation in the rumen so that it will reach post rumen digestive tract compartment where it will be absorbed to the circulatory system.

\section{Formulation of rations containing protected protein}

Several research activities dealing with the use of rumen protected protein are indicated in Table 1 . In formulating ration for ruminants, it should be remembered that the rate of degradation and fermentation of organic materials in the rumen will affect the concentration and production of short-chain volatile fatty acids that can eventually be used as the 


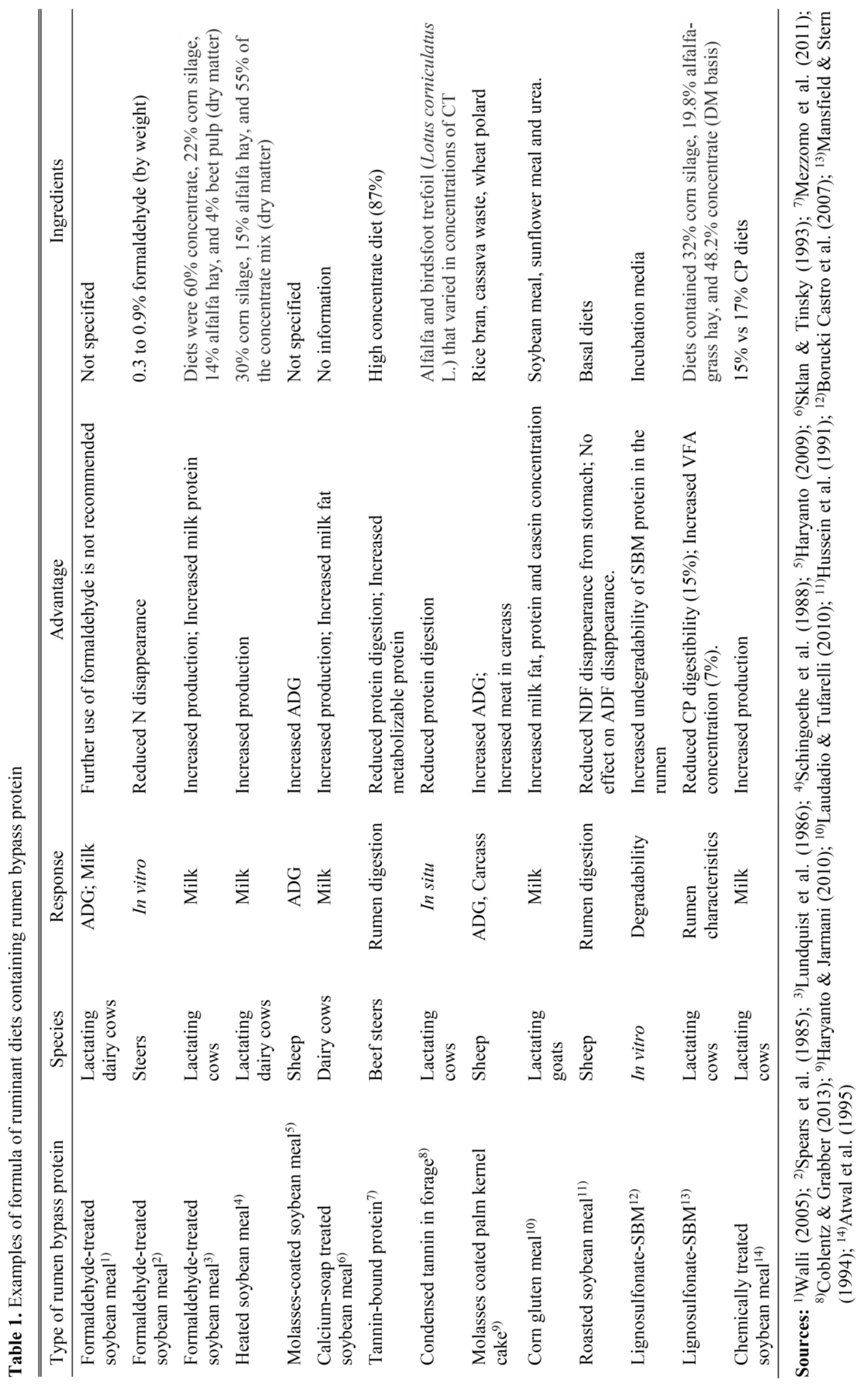


primary source of energy for the animal. The rate of degradation of the dietary protein content should also be considered since the matching concentration of ammonia and energy (Adenosin triphosphate = ATP) in the rumen is important for the optimal production of microbial protein. The fact that microbes are able to use ammonia as source of nitrogen for their protein synthesis, there is common recommendation that urea rather than peptides be supplemented as part of feed to supply nitrogen in the rumen. By this means, the feed cost can be reduced because the price of urea is much less expensive than protein-rich feedstuffs.

Information of chemical characteristics of the feedstuffs is therefore very important for the ration formulation. These include the characteristic on its rate of degradability in the rumen and prices of each feedstuff.

\section{FUTURE RESEARCH IN PROTEIN UTILIZATION}

Techniques for protection of dietary protein from degradation in the rumen remain interesting topic for further experimentation. The available potency of high protein feedstuffs should be explored and need to consider whether or not it requires pretreatment so that the protein will be safely passing the rumen without major degradation of its molecule. There are also of interests to develop substances having the potency for manipulating the population of rumen microbe with special reference on the respective characteristic in producing enzymes such that the ratio of protein, lipid and cellulose degrading bacteria will be optimum. Appropriate technologies for protein protection, either by coating or modifying the microbial population should be concurrently developed.

\section{CONCLUSION}

Manipulating dietary protein characteristics from readily degradable in the rumen to undegradable or partially degradable has the potency to improve the ruminant productivity; therefore further efforts to produce rumen bypass protein feedstuffs will open the possibility to increase farmers' economic benefit.

\section{REFERENCES}

Agle M, Hristov AN, Zaman S, Schneider C, Ndegwa PM, Vaddella VK. 2010. Effect of dietary concentrate on rumen fermentation, digestibility and nitrogen losses in dairy cows. J Dairy Sci. 93:4211-4222.
Annison EF, Bryden WL. 1998. Perspectives on ruminant nutrition and metabolism I. Metabolism in the rumen. Nutr Res Rev. 11:173-198.

Arroquy JI, Cochran RC, Villarreal M, Wickersham TA, Llewellyn DA, Titgemeyer EC, Nagaraja TG, Johnson DE, Gnad D. 2004. Effect of level of rumen degradable protein and type of supplemental nonfiber carbohydrate on intake and digestion of lowquality grass hay by beef cattle. Anim Feed Sci Technol. 115:83-99.

Aschenbach JR, Penner GB, Stumpff F, Gäbel G. 2011. Ruminant nutrition symposium: Role of fermentation acid absorption in the regulation of ruminal $\mathrm{pH}$. J Anim Sci. 89:1092-1107.

Atwal AS, Mahadevan S, Wolynetz MS, Yu Y. 1995. Increased milk production of cows in early lactation fed chemically treated soybean meal. J Dairy Sci. 78:595-603.

Belanche A, Doreau M, Edwards JE, Moorby JM, Pinloche E, Newbold CJ. 2012. Shifts in the rumen microbiota due to the type of carbohydrate and level of protein ingested by dairy cattle are associated with changes in rumen fermentation. J Nutr. 142:1684-1692.

Biricik H, Turkmen II, Deniz G, Gulmez BH, Gencoglu H, Bozan B. 2006. Effects of synchronizing starch and protein degradation in rumen on fermentation, nutrient utilization and total tract digestibility in sheep. Ital J Anim Sci. 5:341-348.

Bohnert DW, Schauer CS, DelCurto T. 2002. Influence of rumen protein degradability and supplementation frequency on performance and nitrogen use in ruminants consuming low-quality forage: cow performance and efficiency of nitrogen use in wethers. J Anim Sci. 80:1629-1637.

Borucki Castro SI, Phillip LE, Lapierre H, Jardon PW, Berthiaume R. 2007. Ruminal degradability and intestinal digestibility of protein and amino acids in treated soybean meal products. J Dairy Sci. 90:810822.

Broderick GA, Stevenson MJ, Patton RA. 2009. Effect of dietary protein concentration and degradability on response to rumen-protected methionine in lactating dairy cows. J Dairy Sci. 92:2719-2728.

Brooks MA, Harvey RM, Johnson NF, Kerley MS. 2012. Rumen degradable protein supply affects microbial efficiency in continuous culture and growth in steers. J Anim Sci. 90:4985-4994.

Calsamiglia S, Cardozo PW, Ferret A, Bach A. 2008. Changes in rumen microbial fermentation are due to a combined effect of type of diet and pH. J Anim Sci. 86:702-711.

Chalupa W. 1975. Rumen bypass and protection of proteins and amino acids. J Dairy Sci. 58:1198-1218. 
Coblentz WK, Grabber JH. 2013. In situ protein degradation of alfalfa and birdsfoot trefoil hays and silages as influenced by condensed tannin concentration. J Dairy Sci. 96:3120-3137.

Crooker BA, Clark JH, Shanks RD. 1983. Effects of formaldehyde treated soybean meal on milk yield, milk composition, and nutrient digestibility in the dairy cow. J Dairy Sci. 66:492-504.

Haryanto B, Jarmani SN. 2010. Performans domba sebagai respons terhadap pemberian pakan mengandung bungkil inti sawit terproteksi molases. Dalam: Prasetyo LH, Natalia L, Iskandar S, Puastuti W, Herawati T, Nurhayati, Anggraeni A, Damayanti R, Dharmayanti N, Estuningsih SE, penyunting. Teknologi peternakan dan veteriner ramah lingkung dalam mendukung program swasembada daging dan peningkatan ketahanan pangan. Semnas Teknologi Peternakan dan Veteriner. Bogor, 3-4 Agustus 2010. Bogor (Indonesia): Puslitbangnak. p. 544-549.

Haryanto B. 1992. Pengaruh tingkat penambahan bungkil kedelai berformaldehid pada pakan konsentrat komersial terhadap produksi karkas domba. Dalam: Prosiding Optimalisasi Sumberdaya dalam Pembangunan Peternakan Menuju Swasembada Protein Hewani. Bogor (Indonesia): ISPI Cabang Bogor. p. 20-23.

Haryanto B. 2008. Paten No. ID0022134. Metode pembuatan bahan pakan ternak sumber protein by-pass rumen.

Haryanto B. 2009. Inovasi teknologi pakan ternak dalam sistem integrasi tanaman-ternak bebas limbah mendukung upaya peningkatan produksi daging. Pengembangan Inovasi Pertanian. 2:163-176.

Hussein HS, Jordan RM, Stern MD. 1991. Ruminal protein metabolism and intestinal amino acid utilization as affected by dietary protein and carbohydrate sources in sheep. J Anim Sci. 69:2134-2146.

Julier B, Guines F, Emile J-C, Huyghe C. 2003. Variation in protein degradability in dried forage legumes. Anim Res. 52:401-412

Kebreab E, Dijkstra J, Bannink A, France J. 2009. Recent advances in modeling nutrient utilization in ruminants. J Anim Sci. 87:E111-E122.

Laudadio V, Tufarelli V. 2010. Effects of pelleted total mixed rations with different rumen degradable protein on milk yield and composition of Jonica dairy goat. Small Rumin Res. 90:47-52.

Lundquist RG, Otterby DE, Linn JG. 1986. Influence of formaldehyde-treated soybean meal on milk production. J Dairy Sci. 69:1337-1345.

Mansfield HR, Stern MD. 1994. Effects of soybean hulls and lignosulfonate-treated soybean meal on ruminal fermentation in lactating dairy cows. J Dairy Sci. 77:1070-1083.

Mezzomo R, Paulino PVR, Detmann E, Valadares Filho SC, Paulino MF, Monnerat JPIS, Duarte MS, Silva LHP, Moura LS. 2011. Influence of condensed tannin on intake, digestibility, and efficiency of protein utilization in beef steers fed high concentrate diet. Livest Sci. 141:1-11.

Min BR, Barry TN, Attwood GT, McNabb WC. 2003. The effect of condensed tannins on the nutrition and health of ruminants fed fresh temperate forages: a review. Anim Feed Sci Technol. 106:3-19.

Mjoun K, Kalscheur KF, Hippen AR, Schingoethe DJ. 2010. Ruminal degradability and intestinal digestibility of protein and amino acids in soybean and corn distillers grains products. J Dairy Sci. 93:4144-4154.

Reynal SM, Broderick GA. 2005. Effect of dietary level of rumen-degraded protein on production and nitrogen metabolism in lactating dairy cows. J Dairy Sci. 88:4045-4064.

Schingoethe DJ, Casper DP, Yang C, Illg DJ, Sommerfeldt JL, Mueller CR. 1988. Lactational response to soybean meal, heated soybean meal, and extruded soybeans with ruminally protected methionine. J Dairy Sci. 71:173-180.

Sinclair LA, Garnsworth PC, Newbold JR, Buttery PJ. 1993. Effect of synchronizing the rate of dietary energy and nitrogen release on rumen fermentation and microbial protein synthesis in sheep. J Agric Sci. 120:251.

Sklan D, Tinsky M. 1993. Production and reproduction responses by dairy cows fed varying undegradable protein coated with rumen bypass fat. J Dairy Sci. 76:216-223.

Spears JW, Clark JH, Hatfield EE. 1985. Nitrogen utilization and ruminal fermentation in steers fed soybean meal treated with formaldehyde. J Anim Sci. 60:1072-1080.

Supriyati, Haryanto B. 2011. Bungkil inti sawit terproteksi molases sebagai sumber protein pada Kambing Peranakan Etawah jantan muda. JITV. 16:17-24.

Tamminga S. 2006. The effect of the supply of rumen degradable protein and metabolisable protein on negative energy balance and fertility in dairy cows. Anim Reprod Sci. 96:227-239.

Wagner JJ, Engle TE, Bryant TC. 2010. The effect of rumen degradable and rumen undegradable intake protein on feedlot performance and carcass merit in heavy yearling steers. J Anim Sci. 88:1073-1081.

Walli TK. 2005. Bypass protein technology and the impact of feeding bypass protein to dairy animals in tropics: a review. Indian J Anim Sci. 75:135-142. 